\title{
Empirical Evidence of Economic Bipolarization in Africa
}

\author{
Mbaye Diene \\ Faculty of Economics and Management, CRES (Economic and Social Research Consortium), UCAD (University Cheikh Anta Diop of \\ Dakar), Rue de Kaolack Angle F, Rond Point de l'OEuf, Point E., C.P. 12023, B.P. 7988, Dakar-Médina, Senegal
}

Correspondence should be addressed to Mbaye Diene, mbayedienesnl@yahoo.ca

Received 9 January 2011; Revised 30 May 2011; Accepted 31 May 2011

Academic Editor: Thanasis Stengos

Copyright (C) 2011 Mbaye Diene. This is an open access article distributed under the Creative Commons Attribution License, which permits unrestricted use, distribution, and reproduction in any medium, provided the original work is properly cited.

This paper examines the degree of polarization in African countries' per capita GDP distribution between 1966 to 2004 . We first use a nonparametric analysis and find that the countries tend to cluster in two classes of per capita GDP. Secondly, by using the Wolfson's bipolarization measure, the results reveal that bipolarization has been accelerating during the two first decades and is still growing. We relate the evolution of polarization during the period to the business sectors. We find that the specialization of the countries is the main factor explaining its evolution, namely, in agriculture and industry sectors.

\section{Introduction}

The great advances recently done in economic growth theory, coinciding with the introduction of endogenous growth models $[1,2]$, have led to a rising attention on the issue of economic disparities. The models usually take into account other determinants of growth, different from capital and labor, such as human capital, public expenditures [3], and innovations [4]. Economic growth theories enhanced by the "new economic geography" models [5-7] show the importance of spatial disparities in the convergence of economies.

Usually, the sigma and beta convergence developed by Barro and Sala-i-Martin [8, 9] are used for the analyses of the disparities in per capita GDP in the literature. But some authors [10-13] have shown that the convergence methodologies lead to loss of information on the dynamics of the GDP distribution. For example, they cannot capture the changes of relative positions of countries over the period, letting behind the intragroup mobility.

Analysis of per capita convergence between countries has also been done by some authors: López-Bazo et al. [14], Cuadrado and Parellada [15], Fingleton and López-Bazo [16], Badinger et al. [17], Magrini [18], Miller and Genc [19], and Meliciani [20].

Bernard and Durlauf [21] use annual logarithm of real output per capita for 15 OECD countries and test the existence of convergence and common trends, from 1900 to
1987. There is a convergence for a group of countries when they have identical either stochastic or deterministic longrun trends, while common trends allow for proportionality of the stochastic elements. They found that there is no convergence for the countries but evidence for common trends exists.

Bernard and Durlauf [22], Quah [12], and Anderson [23] point out that the convergence approaches also ignore the role of the polarization or formation of homogeneous groups within the distributions. The natural clustering around stable steady state equilibria is identified as the formation of "convergence clubs" [13, 24-26].

But some important issues arise from the studies of convergences such as the existence of threshold effects [27], of nonlinearity and parameter heterogeneity of human capital [26, 28-31] (Mamuneas et al., [32]).

About the nonlinearities, Kalaitzidakis et al. [29] notice that "though intuition and theories point towards a positive effect of human capital on growth, the empirical evidence of the issue is mixed". So, they apply semiparametric estimation techniques that investigate nonlinearities in the relationship between economic growth and human capital (measured by mean of years of schooling). They conclude that the link between the two variables is widely nonlinear.

Several empirical studies with different methodological approaches show strong evidence of parameter heterogeneity $[26,29,33,34]$. Parameter heterogeneity in growth models 
means, for example, that in a cross-country growth regression, countries have different coefficient estimates [27, 35, 36].

Our paper examines the degree of economic polarization in Africa, using the per capita GDP distribution. The relevance of the issue of polarization in Africa is mainly due to the necessity of achieving economic and social cohesion in the context of the economic integration process underway since the years of independence. It is then necessary to reduce the differences in terms of development across the continent. This necessity may be seriously threatened if the African Union (AU) and other regional integration institutions were to split into series of well-differentiated economic clusters.

We show that there exists a bipolarization of the economies by using three methodologies. We primarily estimate nonparametrically the distribution of the per capita GDP (we precisely use the GDP per capita in 2000 constant dollar terms) in 34 African countries, aiming to identify multimodality of the distributions, during the period 19662004. But the methodology does not give precise measure of the observed changes in the degree of polarization over time. That is why we secondly analyze the evolution of Wolfson's bipolarization index during the period. For this purpose, we find how the global bipolarization is explained by the polarization into four sectors: agriculture, mining, industries, and services. The paper is based on data drawn from the World Bank Africa Database (2007).

The rest of the paper is organized as follows: Section 1 presents the nonparametric analysis of the distribution of per capita GDP in the African countries. In Section 2, we measure the degree of bipolarization of the countries and examine the transitions of the economies during the period. We end by the main conclusions and some policy implications.

\section{The Per Capita GDP Distribution: A Nonparametric Analysis}

We examine the external shape of the GDP per capita distribution during the period 1966-2004 for 34 countries. We exclude some countries due to data problems. To this end, we have estimated nonparametrically the density functions of the distribution under consideration. Estimates are based on Epanechnikov kernel functions, and in each case, the smoothing parameter is determined following Silverman [37, page 48]. The results are robust to the kernel function used. The results are presented in Figure 1, where for reasons of comparability, we have normalized the data by per capita GDP average for the various years. There appear different patterns in the evolution of the African countries over time, and Figure 1 displays tendencies to cluster into relatively homogenous classes, which are also commonly referred to as "convergence clubs" in Durlauf and Johnson [26] and Quah $[12,13]$.

Here, we plot the kernel density of the logarithm of GDP per capita for all the countries, normalized by the log of the regional per capita GDP, from 1996 to 2004. As we

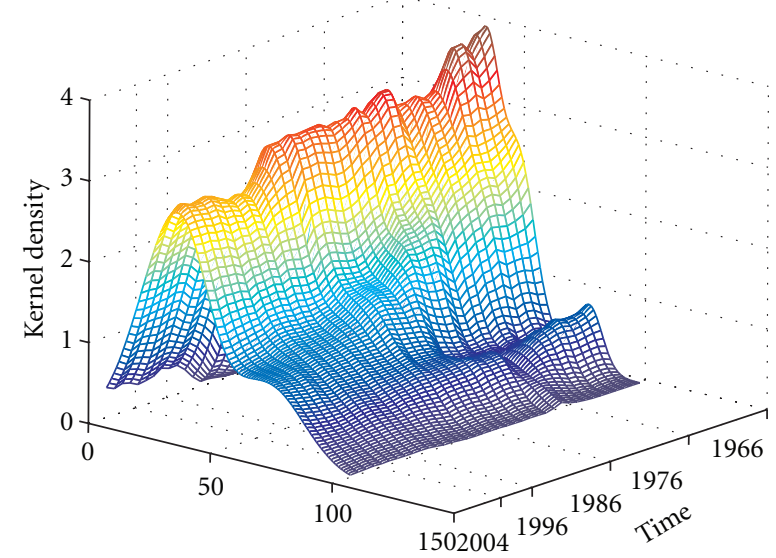

FIGURE 1: Density estimations of the relative GDP per capita.

can see, the African countries have evolved towards a twinpeak situation shown by Quah [12] for the world economy. The upper tail has stretched out further during the last two decades. The distribution has also lost mass at the low end, particularly during the last period. So, the poorest countries are not trapped in their relative GDP positions.

The third mode that appears very apparent since 1966 begins to diminish continuously towards the end of the period. From 1986 onwards, only a second mode emerged in all the estimated density functions. This mode was formed by most developed countries, in the south and the north of Africa, such as Morocco, Tunisia, and South Africa. This suggests that these countries are converging toward a higher per capita GDP level than the others.

It is worth noting that the changes in the shape of the distribution of per capita GDP do not derive from volatile movements, as shown by the fact that about three quarters of the countries stay in their income class over a period of ten years, as shown in Table 2 in the Appendix.

It appears in the transition probabilities that the countries of the third group are mainly located in the north and the south of Africa, with some exceptions as Gabon and Congo. In the first decades, some countries quit the second group for the less developed first one, such as Ivory Coast and Liberia. Other countries made transition from the first to the second group: Egypt, Congo, and Botswana.

The nonparametric and the transition approaches present the limitation that they do not provide information about changes in the degree of polarization over time. To tackle this issue, we use the methodology proposed by Wolfson [38] in the literature on income distribution.

\section{Quantification of the Level of Polarization}

Let $F$ be an income distribution of $N$ countries with a mean income value $y$ and a median income value $y_{m}$. Wolfson's bipolarization index, given for a population divided in two groups by the median, is

$$
W(F)=4 \frac{\bar{y}}{y_{m}}[1-2 L(0.5)-G(F)],
$$


TABLE 1: Distribution of the countries between the groups.

\begin{tabular}{|c|c|c|c|c|c|c|c|c|c|c|c|}
\hline Countries & 1966 & 1976 & 1985 & 1996 & 2003 & Countries & 1966 & 1976 & 1985 & 1996 & 2003 \\
\hline Algeria & 2 & 2 & 2 & 2 & 2 & Liberia & 2 & 1 & 1 & 1 & 1 \\
\hline Benin & 1 & 1 & 1 & 1 & 1 & Madagascar & 1 & 1 & 1 & 1 & 1 \\
\hline Botswana & 1 & 1 & 2 & 2 & 2 & Malawi & 1 & 1 & 1 & 1 & 1 \\
\hline Burkina Faso & 1 & 1 & 1 & 1 & 1 & Mauritania & 1 & 1 & 1 & 1 & 1 \\
\hline Burundi & 1 & 1 & 1 & 1 & 1 & Morocco & 2 & 2 & 2 & 2 & 2 \\
\hline Cameroon & 1 & 1 & 2 & 1 & 1 & Niger & 1 & 1 & 1 & 1 & 1 \\
\hline $\begin{array}{l}\text { Central A } \\
\text { Republic }\end{array}$ & 1 & 1 & 1 & 1 & 1 & Nigeria & 1 & 1 & 1 & 1 & 1 \\
\hline Chad & 1 & 1 & 1 & 1 & 1 & Rwanda & 1 & 1 & 1 & 1 & 1 \\
\hline Congo & 2 & 1 & 2 & 2 & 1 & Senegal & 1 & 1 & 1 & 1 & 1 \\
\hline $\begin{array}{l}\text { Congo. D. } \\
\text { Republic }\end{array}$ & 1 & 1 & 1 & 1 & 1 & Seychelles & 2 & 2 & 2 & 2 & 2 \\
\hline Cote d Ivoire & 2 & 2 & 1 & 1 & 1 & Sierra Leone & 1 & 1 & 1 & 1 & 1 \\
\hline Egypt & 1 & 1 & 2 & 2 & 2 & $\begin{array}{l}\text { South } \\
\text { Africa }\end{array}$ & 2 & 2 & 2 & 2 & 2 \\
\hline Gabon & 2 & 2 & 2 & 2 & 2 & Sudan & 1 & 1 & 1 & 1 & 1 \\
\hline Gambia The & 1 & 1 & 1 & 1 & 1 & Togo & 1 & 1 & 1 & 1 & 1 \\
\hline Ghana & 1 & 1 & 1 & 1 & 1 & Tunisia & 2 & 2 & 2 & 2 & 2 \\
\hline Kenya & 1 & 1 & 1 & 1 & 1 & Zambia & 1 & 1 & 1 & 1 & 1 \\
\hline Lesotho & 1 & 1 & 1 & 1 & 1 & Zimbabwe & 1 & 1 & 1 & 1 & 1 \\
\hline
\end{tabular}

GDP per capita share

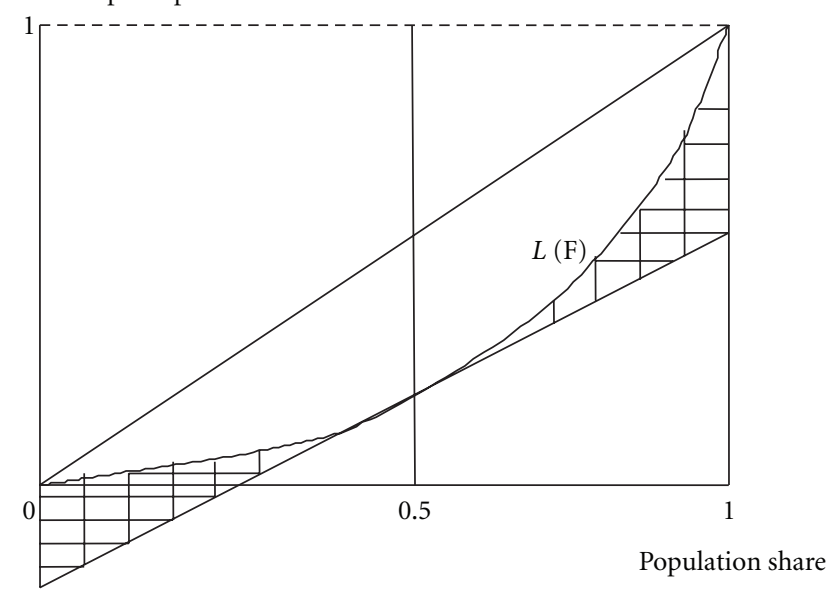

FIgURE 2: The bipolarization index.

$G(F)$ is the Gini coefficient of the income of the distribution $F$ and Lorenz curve $(L)$ at the 50th population percentile. $W(F)$ is proportional to the shaded area in Figure 2. The larger the shaded area is, the fewer countries with middle level GDP per capita are, leading to a greater polarization. The area is also algebraically equal to the vertical distance between the 45-degree line and the Lorenz curve at the median percentile, $L(0.5)$.

3.1. Economic Bipolarization. Figure 3 presents the evolution of Wolfson's bipolarization measure over time. Taking the

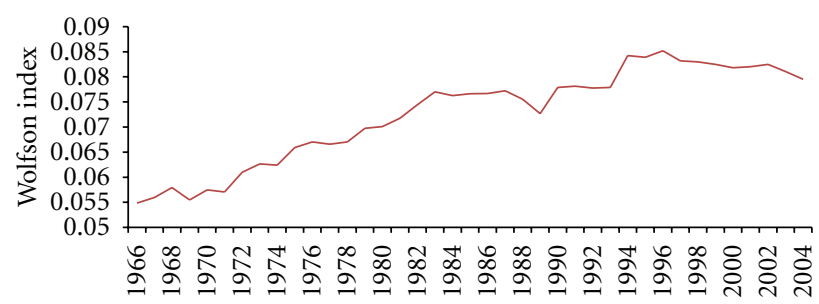

FIgURE 3: Evolution of the bipolarization index.

study period as a whole, the results reveal an increase in the bipolarization of the distribution under consideration. The African countries are economically polarized, and there appears to be an increase of the polarization during the first two decades. The trend of increase of polarization is permanent, except in 1988.

As it appears in Table 1 of the appendices, the evolution of bipolarization means that we can divide the countries into two groups economically different. The first group (group 1) comprises the countries which remain below the regional per capita GDP during all the periods 1966-19761985-1993-2003. Within this group are countries as Benin, Burkina Faso, Burundi, Central African Republic, Chad, Congo Democratic Republic, The Gambia, Togo, and so forth.

The group 2 is the set of countries that have their level of GDP per capita higher the regional one during all the period: Algeria, Morocco, Egypt, Tunisia, South Africa, and so forth. That is why, except of Gabon and Congo, we can 
TABLe 2: The transition matrices.

(a) Period 1966-1976

\begin{tabular}{lccc}
\hline & \multicolumn{3}{c}{76} \\
66 & $0,6-1,0$ & $1,0-1,4$ & Total \\
\hline $0,6-1,0$ & 0,735 & 0 & 0,735 \\
$1,0-1,4$ & 0,059 & 0,206 & 0,265 \\
Total & 0,794 & 0,206 & 1 \\
\hline
\end{tabular}

(b) Period 1976-1985

\begin{tabular}{lccc}
\hline & & 85 & \\
76 & $0,6-1,0$ & $1,0-1,4$ & Total \\
\hline $0,6-1,0$ & 0,676 & 0,118 & 0,794 \\
$1,0-1,4$ & 0,029 & 0,176 & 0,206 \\
Total & 0,706 & 0,294 & 1 \\
\hline
\end{tabular}

Sources: Author's calculation.

(c) Period 1985-1996

\begin{tabular}{lccc}
\hline & \multicolumn{3}{c}{96} \\
85 & $0,6-1,0$ & $1,0-1,4$ & Total \\
\hline $0,6-1,0$ & 0,706 & 0 & 0,706 \\
$1,0-1,4$ & 0,029 & 0,265 & 0,294 \\
Total & 0,735 & 0,265 & 1 \\
\hline
\end{tabular}

(d) Period 1996-2003

03

\begin{tabular}{lccc}
96 & $0,6-1,0$ & $1,0-1,4$ & Total \\
\hline $0,6-1,0$ & 0,735 & 0 & 0,735 \\
$1,0-1,4$ & 0,029 & 0,235 & 0,265 \\
Total & 0,765 & 0,235 & 1 \\
\hline
\end{tabular}

suppose that we have three geographical groups: The subSaharan countries, the Maghreb countries, and the Southern African countries. The growing bipolarization means that the development of the first two groups of countries has not a visible and direct effect on the remaining countries. It means also that there are not very tight economic relationships, such as mobility of the factors or international exchanges, between these two groups and the rest of the countries in the continent.

3.2. Explanatory Elements of Bipolarization: An Analysis by Sectors. In the previous section, the Africa region are divided into two groups according to their per capita GDP. Nevertheless, there are other national characteristics, instead of the per capita GDP only, that may explain polarization. For the aim of capturing those characteristics, we estimate the polarization index on the value added of the four sectors: agriculture, mining, industries, and services so as to understand the dynamics of the global polarization.

The sectors with the greatest bipolarization level are mining and services. It means that the natural resources make the countries different.
We run the following simple dynamic estimation:

$$
\mathrm{GI}_{t}=F\left(\mathrm{AP}_{t}, \mathrm{AP}_{t}-1, \mathrm{MP}_{t}, \mathrm{IP}_{t}, \mathrm{IP}_{t}-1, \mathrm{SP}_{t}, \mathrm{SP}_{t-1}\right),
$$

where $F$ is a function, $t$ stands for the time, $\mathrm{GI}_{t}$ is the global index at time $t, \mathrm{AP}_{t}$ is the polarization index in agriculture, $\mathrm{MP}_{t}$ is the polarization index in mining sector, $\mathrm{IP}_{t}$ is the polarization index for industries, and $\mathrm{SP}_{t}$ is the index for services.

We find the following results:

$$
\begin{aligned}
\mathrm{GI}_{t}= & 0,019 \mathrm{AP}_{t}+0,022 \mathrm{AP}_{t-1}-0,004 \mathrm{MP}_{t} \\
& -0,0005 \mathrm{MP}_{t-1}+0,0039 \mathrm{IP}_{t}+0,0033 \mathrm{IP}_{t-1} \\
& -0,085 \mathrm{SP}_{t}-0,0156 \mathrm{SP}_{t-1}+0,064
\end{aligned}
$$

The main sectors that tend to reduce bipolarization are mining and the services. Agriculture and industries and their lagged bipolarization level contribute to enhance the global clustering between the African countries. At the level of 5\%, the lagged values of polarization in mines and services are significant.

It is possible to run other regressions by changing the variable or by supposing nonlinearities in the relation. But the simple model emphasizes that most of the African countries have similarities on the services and mines.

\section{Conclusion}

Aiming to contribute to the findings of convergence studies, this paper examines the degree of polarization in the per capita GDP distribution in the African countries between 1966 and 2004 from complementary approaches. We begin primarily by a nonparametric analysis. It shows that the African countries tend to cluster into two classes over the period. However, the level of intradistribution mobility, is low and can be attributed mainly to the sub-Saharan countries. Indeed, the geographical location of the countries plays an important role in the explanation of the bi-polarization patterns. Secondly, we construct the evolution of the level of polarization over time, completing the nonparametric approach by using the methodology proposed by Wolfson [38] . The results reveal a growing bipolarization. The Maghreb Arab countries and the southern African countries constitute a cluster and the sub-Saharan countries another one.

The growth of polarization is related to the specialization of the countries during the period. Essentially, its evolution is the outcome of agriculture and industry.

So, development policies for the sectors of services and mining may be very useful for the decrease of polarization in Africa. A very common service in Africa is trade in the informal sector that contributes to uniform the economies. 
TABLE 3: The regression results.

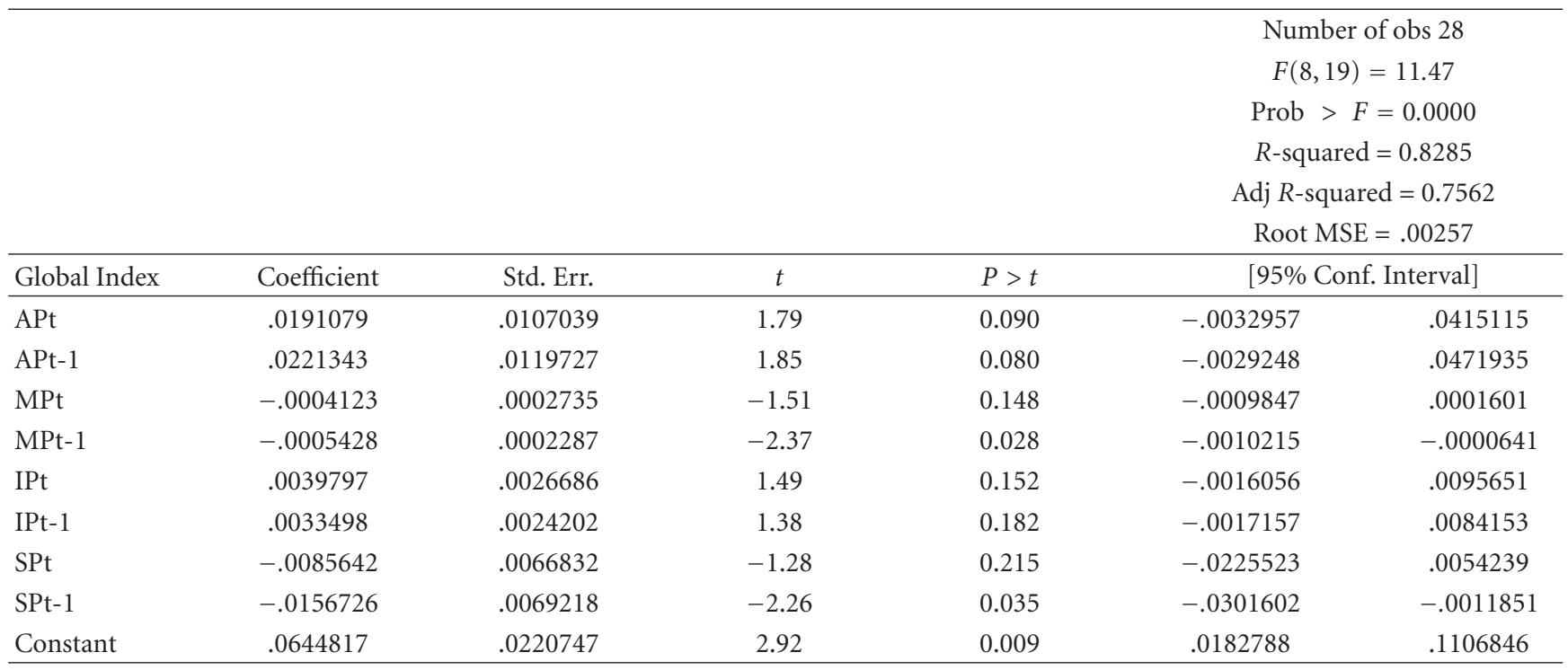

\section{Appendix}

See Tables 1, 2, and 3 .

\section{Acknowledgments}

The author also wishes to thank the anonymous referee for helpful comments and suggestions that greatly improve the paper. He also thanks Pr. Theophile Azomahou and Daniel Opolot from the University of Maastricht who helped him by their comments.

\section{References}

[1] P. Romer, "Increasing returns and long-run growth," The Journal of Political Economy, vol. 94, pp. 1002-1037, 1986.

[2] P. Romer, "Growth based on increasing returns due to specialization," American Economic Review, vol. 77, pp. 56-62, 1987.

[3] R. E. Lucas, "On the mechanics of economic development," Journal of Monetary Economics, vol. 22, no. 1, pp. 3-42, 1988.

[4] G. Grossman and E. Helpman, "Endogenous innovation in the theory of growth," The Journal of Economic Perspectives, vol. 8, pp. 23-44, 1994.

[5] P. Krugman, "Increasing returns and economic geography," Journal of Political Economy, vol. 99, no. 3, pp. 483-499, 1991.

[6] M. Fujita, P. Krugman, and A. Venables, The Spatial Economy, MIT Press, Cambridge, UK, 1999.

[7] M. Fujita and J. F. Thisse, Economics of Agglomeration, Cambridge University Press, Cambridge, UK, 2002.

[8] R. Barro and X. Sala-I-Martin, "Convergence across states and regions," Brookings Papers on Economic Activity, vol. 1991, no. 1, pp. 107-182, 1991.

[9] R. J. Barro and X. Sala-I-Martin, "Convergence," Journal of Political Economy, vol. 100, pp. 407-443, 1992.

[10] D. Quah, "Empirical cross-section dynamics in economic growth," European Economic Review, vol. 37, no. 2-3, pp. 426434, 1993.
[11] D. T. Quah, "Empirics for economic growth and convergence," European Economic Review, vol. 40, no. 6, pp. 1353-1375, 1996.

[12] D. T. Quah, "Twin peaks: growth and convergence in models of distribution dynamics," Economic Journal, vol. 106, no. 437, pp. 1045-1055, 1996.

[13] D. T. Quah, "Empirics for growth and distribution: stratification, polarization, and convergence clubs," Journal of Economic Growth, vol. 2, no. 1, pp. 27-59, 1997.

[14] E. López-Bazo, E. Vayá, A. J. Mora, and J. Suriñach, "Regional economic dynamics and convergence in the European Union," Annals of Regional Science, vol. 33, no. 3, pp. 343-370, 1999.

[15] J. R. Cuadrado and M. Parellada, Eds., Regional Convergence in the European Union, Facts, Prospects and Policies, Springer, New York, NY, USA, 2002.

[16] B. Fingleton and E. López-Bazo, "Explaining the distribution of manufacturing productivity in the EU regions," in European Regional Growth, B. Fingleton, Ed., pp. 375-410, Springer, New York, NY, USA, 2003.

[17] H. Badinger, W. G. Müller, and G. Tondl, "Regional convergence in the European Union 1985-1999: a spatial dynamic panel analysis," Regional Studies, vol. 38, no. 3, pp. 241-253, 2004.

[18] S. Magrini, "Regional (di)convergence," in Handbook of Regional and Urban Economics, J. V. Henderson and J. F. Thisse, Eds., Elsevier, New York, NY, USA, 2004.

[19] J. R. Miller and I. Genc, "Alternative regional specification and convergence of U.S. regional growth rates," Annals of Regional Science, vol. 39, no. 2, pp. 241-252, 2005.

[20] V. Meliciani, "Income and employment disparities across European regions: The role of national and spatial factors," Regional Studies, vol. 40, no. 1, pp. 75-91, 2006.

[21] A. B. Bernard and S. N. Durlauf, "Convergence in international output," Journal of Applied Econometrics, vol. 10, no. 2, pp. 97-108, 1995.

[22] A. B. Bernard and S. N. Durlauf, "Interpreting tests of the convergence hypothesis," Journal of Econometrics, vol. 71, no. 1-2, pp. 161-173, 1996.

[23] G. Anderson, "Toward an empirical analysis of polarization," Journal of Econometrics, vol. 122, no. 1, pp. 1-26, 2004. 
[24] W. J. Baumol, "Productivity growth, convergence and welfare," The American Economic Review, vol. 76, no. 5, pp. 1072-1085, 1986.

[25] O. Galor, "Convergence? Inferences from theoretical models," Economic Journal, vol. 106, no. 437, pp. 1056-1069, 1996.

[26] S. N. Durlauf and P. A. Johnson, "Multiple regimes and crosscountry growth behaviour," Journal of Applied Economics, vol. 10, pp. 365-384, 1995.

[27] C. Azariadis and A. Drazen, "Threshold externalities in economic development," Quarterly Journal of Economics, vol. 105, no. 2, pp. 501-526, 1990.

[28] W. H. Masanjala and C. Papageorgiou, "The solow model with ces technology: nonlinearities and parameter heterogeneity," Journal of Applied Econometrics, vol. 19, no. 2, pp. 171-201, 2004.

[29] P. Kalaitzidakis, T. P. Mamuneas, A. Savvides, and T. Stengos, "Measures of human capital and nonlinearities in economic growth," Journal of Economic Growth, vol. 6, no. 3, pp. 229 254, 2001.

[30] E. Ketteni, T. P. Mamuneas, and T. Stengos, "Nonlinearities in economic growth: a semiparametric approach applied to information technology data," Journal of Macroeconomics, vol. 29, no. 3, pp. 555-568, 2007.

[31] E. Ketteni, "Information technology and economic performance in U.S industries," Canadian Journal of Economics, vol. 42, no. 3, pp. 844-865, 2009.

[32] T. Mamuneas, A. Savvides, and T. Stengos, "Economic development and the return to human capital: A smooth coefficient semiparametric approach," Journal of Applied Econometrics, vol. 21, no. 1, pp. 111-132, 2006.

[33] C. Liu and T. Stengos, "Non-linearities in cross-country growth regressions: a semiparametric approach," Journal of Applied Econometrics, vol. 14, no. 5, pp. 527-538, 1999.

[34] S. N. Durlauf, A. Kourtellos, and A. Minkin, "The local Solow growth model," European Economic Review, vol. 45, no. 4-6, pp. 928-940, 2001.

[35] S. Durlauf, "Nonergodic economic growth," Review of Economic Studies, vol. 60, pp. 349-366, 1993.

[36] O. Galor and J. Zeira, "Income distribution and macroeconomics," Review of Economic Studies, vol. 60, pp. 35-52, 1993.

[37] B. W. Silverman, "Density estimation for statistics and data analysis," in Monographs on Statistics and Applied Probability, vol. 26, Chapman \& Hall, London, UK, 1986.

[38] M. Wolfson, "When inequalities diverge," American Economic Review, vol. 84, pp. 353-358, 1994. 


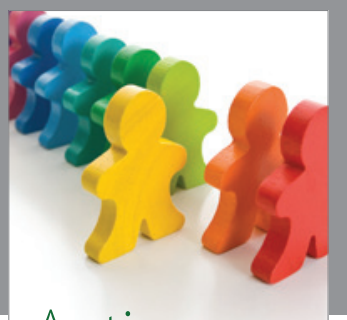

Autism

Research and Treatment
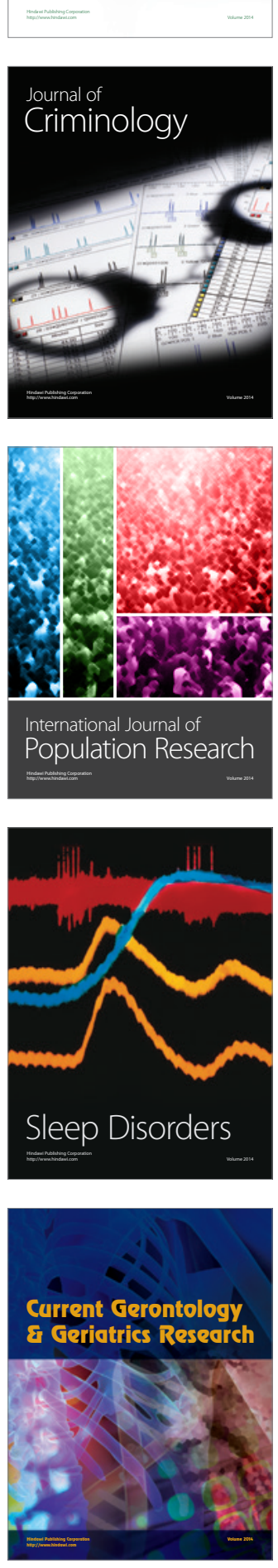
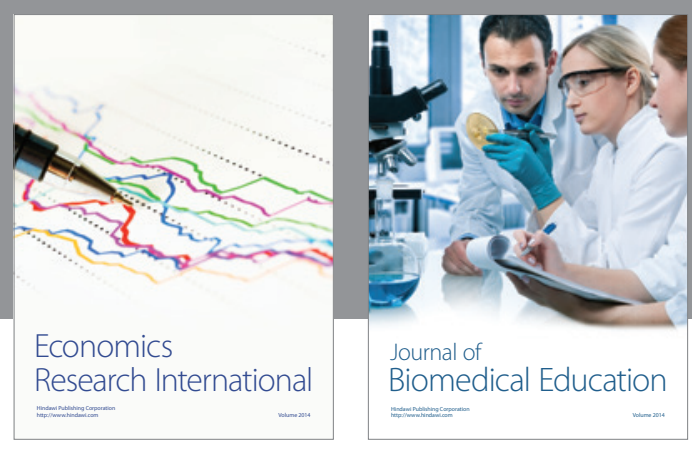

Journal of

Biomedical Education

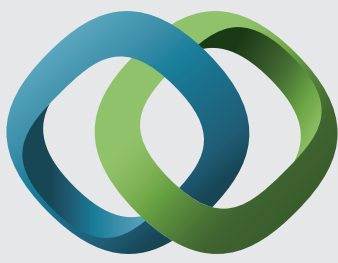

\section{Hindawi}

Submit your manuscripts at

http://www.hindawi.com
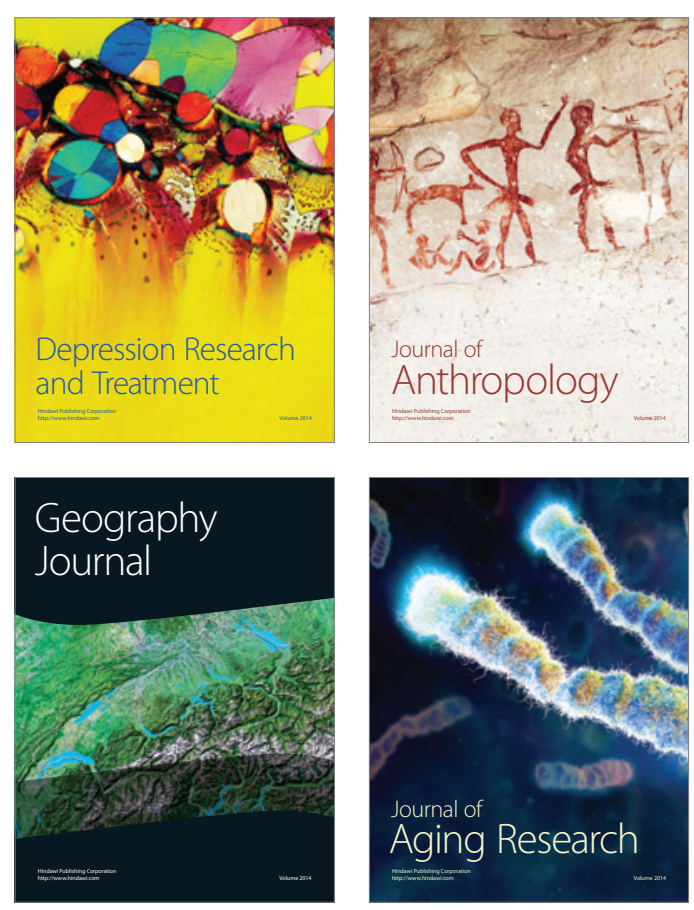

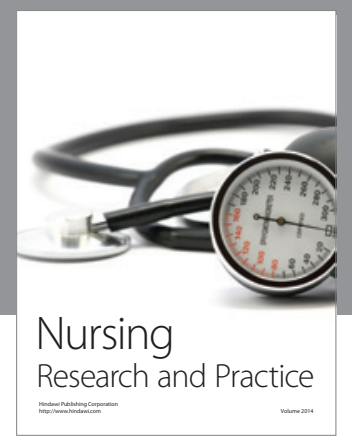

Nursing

Research and Practice

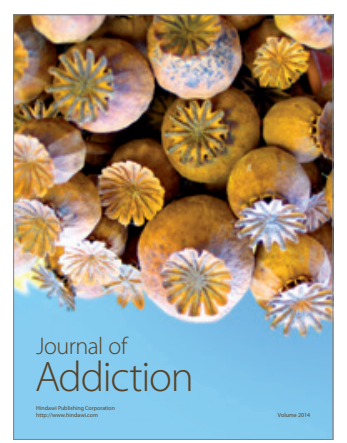

Child Development

Research

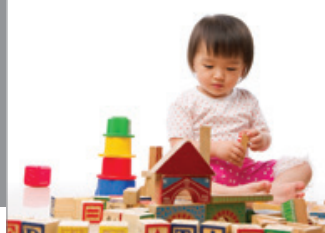

迥
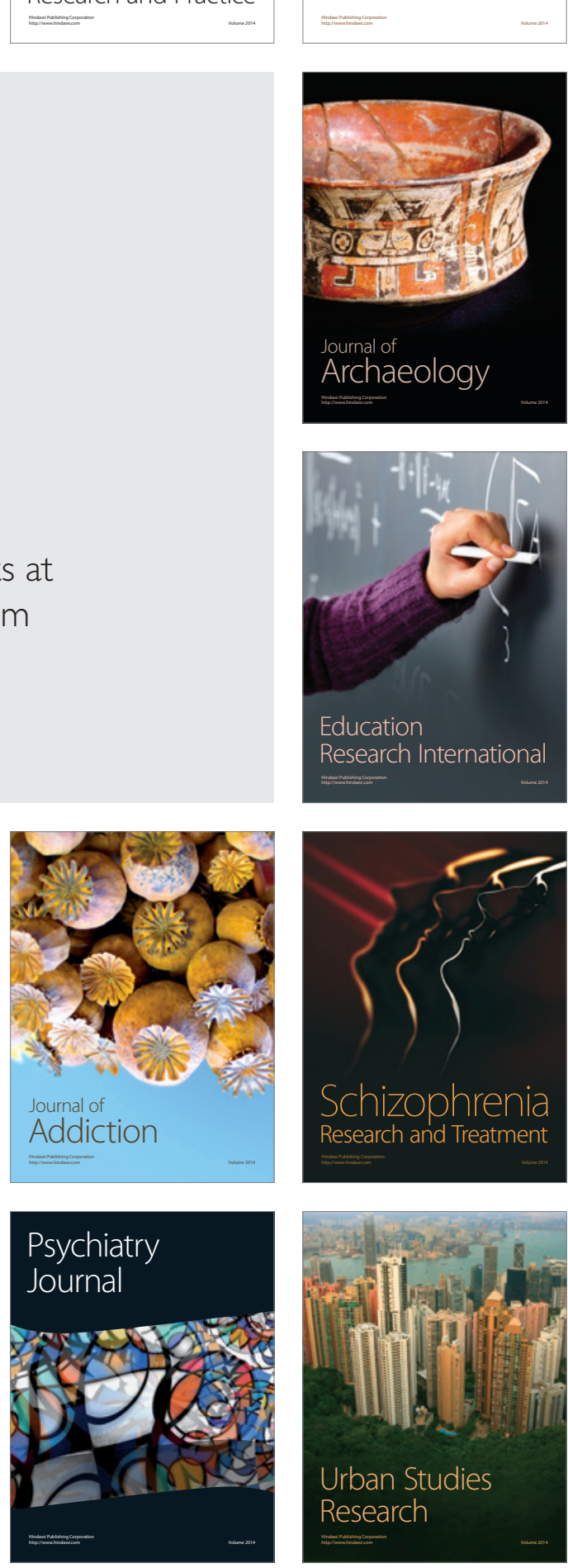